\title{
Monitoring the natural attenuation of a sewage sludge toxicity using the Allium cepa test
}

\author{
Dânia Elisa Christofoletti Mazzeo a, Thaís Cristina Casimiro Fernandes ${ }^{\mathrm{a}}$, \\ Carlos Emílio Levy ${ }^{\mathrm{b}}$, Carmem Silvia Fontanetti ${ }^{\mathrm{a}}$, Maria Aparecida Marin-Morales ${ }^{\mathrm{a}, *}$ \\ a Department of Biology, Institute of Biosciences, UNESP-Univ Estadual Paulista, Av. 24-A, 1515, 13506-900 Rio Claro, SP, Brazil \\ ${ }^{\mathrm{b}}$ Department of Clinical Pathology, Faculty of Medical Sciences, State University of Campinas-UNICAMP, Rua Alexander Fleming, 105, \\ 13081-970 Campinas, SP, Brazil
}

\section{A R T I C L E I N F O}

\section{Article history:}

Received 8 September 2014

Received in revised form 13 March 2015

Accepted 23 March 2015

\section{Keywords:}

Solid waste

Waste management

Micronucleus

Chromosomal aberration

Genotoxicity

Cytotoxicity

\begin{abstract}
A B S T R A C T
Appropriate final disposal of sewage sludge (SS) generated by wastewater treatment plants (WWTP) has been considered a serious environmental problem, but also a viable alternative to be applied in agriculture, once SS is rich in organic matter and nutrients. However, SS can be a source of contamination of several toxic agents. Therefore, its use in agriculture requires special care to avoid possible damage to the environment and exposed organisms. Detoxification of toxic wastes can be performed using the monitored natural attenuation, which involves biological, physical and chemical processes that frequently occur in the environment. This study aimed to assess the feasibility of decontaminating SS after different periods of monitored natural attenuation. To this end, samples of SS and associations of soil/SS with proportions of 10, 25 and 50\% SS were buried for 0, 2, 6 and 12 months in holes prepared in a place free of contamination. Allium cepa was used as an indicator to assess the efficiency of the natural attenuation process. According to chemical analysis, the SS samples presented a high concentration of $m$ - and $p$-cresol, especially for samples analyzed after 0 or 2 months of natural attenuation. The microorganisms present in the SS belonged to 17 different genera of bacteria, which varied in the microbial composition among samples. Both, raw SS and aqueous SS extracts induced DNA damage in A. cepa, even when associated with soil. However, this effect was observed to decline during the attenuation period, although significant effects were detected for the highest tested concentration (100\% SS) even at the end of this process. These results thus indicated the necessity of applying a stabilization process associating SS and soil for a period of at least 12 months and showed that the studied raw SS is not a viable material for use as a soil reconditioner, even after natural attenuation. A. cepa test proved to be a useful tool to assess the efficiency of SS detoxification process. Therefore, we suggest that the application of SS in agriculture should be approached with caution and that the SS must be previously submitted to methodologies that evaluate its toxic potential.
\end{abstract}

(c) 2015 Elsevier Ltd. All rights reserved.

\section{Introduction}

Sewage sludge (SS) is a semi-solid residue resulting from the treatment of urban or industrial effluents. Although SS presents a quite variable composition, it is rich in organic matter, nitrogen and phosphorus and may contain other nutrients such as potassium, calcium and magnesium (Gray, 2010). Because SS contains a high concentration of organic matter and some basic elements required

\footnotetext{
* Corresponding author. Tel.: +55 193526 4143; fax: +55 1935360009.

E-mail addresses: daniamazzeo@gmail.com (D.E.C. Mazzeo), tccfbio@rc.unesp.br (T.C.C. Fernandes), celevy@fcm.unicamp.br (C.E. Levy), fontanet@rc.unesp.br (C.S. Fontanetti), mamm@rc.unesp.br (M.A. Marin-Morales).
}

for plants, it can be characterized as a viable alternative for fertilizer in agricultural areas and/or as a reconditioner of the physical, chemical and biological properties of soil (Sánchez-Brunete et al., 2007).

The use of SS in agricultural activities can be characterized as a promising destination for this residue, both economically and environmentally, as the production of SS in urbanized areas continues to increase because of the constant growth of the amount of sewage produced by humans (Bright and Healey, 2003). However, SS may contain chemical contaminants such as metals and toxic organic compounds as well as pathogenic microorganisms (Holmstrup et al., 2001; Tsakou et al., 2001), which may result in soil degradation. Therefore, the use of SS in agriculture requires special care to avoid possible damage to the environment and to 
directly exposed organisms, including humans (Clarke and Smith, 2011).

The use of SS contaminated with metals, organic pollutants and pathogens in agricultural soils can affect functionality and edaphic biodiversity (Tas, 2010), which in the long term, can impact the entire associated food chain (Roig et al., 2012). Another problem is possible chemical lixiviation of SS-treated soils by pluvial waters, which can transfer this contamination to superficial and subterranean waters (Keller et al., 2002). These issues have stimulated worldwide efforts to develop new technologies to optimize the fate of SS (Tas, 2010).

Monitored natural attenuation is considered an advantageous remediation methodology for decreasing the toxicity of organic wastes because it is efficient, inexpensive and environmentally friendly (Makadia et al., 2011).

According to USEPA (1999a) the monitored natural attenuation can be defined as a process that occurs under favorable conditions in the environment, resulting in a decrease of the mass, toxicity, mobility, volume or concentration of contaminants as a consequence of a variety of physical, chemical or biological processes, such as biodegradation, dispersion, dilution, adsorption, volatilization, transformation and others.

The chemical analysis of environmental samples is extremely important for characterizing damage in contaminated areas. However, chemical analysis only estimates the concentrations of toxic substances in the environment and does not reflect the bioavailability of these chemicals to the associated biota (Moreira et al., 2008). Thus, it has become increasingly important to conduct bioassays that can establish the real impact of contaminants on the environment (Plaza et al., 2005). Bioassays allow the observation of isolated or combined effects of substances present in the environment and may therefore reveal the complexity of the associated biochemical and physiological processes (Roos et al., 2004).

The species Allium cepa has frequently been used to evaluate the effectiveness of environmental decontamination processes because it presents suitable biomarkers of cellular and genetic damages (Mazzeo et al., 2010, 2011; Miranda et al., 2013; Souza et al., 2013).

This study aimed to evaluate the effectiveness of monitored natural attenuation of domestic SS by means of bioassays using the test organism A. cepa to comparatively evaluate the cytotoxic, genotoxic and mutagenic potential of the SS before and after different periods of the attenuation process.

\section{Materials and methods}

\subsection{Material and sample preparation}

Samples of anaerobic SS, dewatered via centrifugation, were collected from a wastewater treatment plant (WWTP) that receives only effluents from domestic sewage, located in the municipality of Rio Claro, São Paulo, Brazil (latitude $22^{\circ} 24^{\prime} 39^{\prime \prime} S$ and longitude $47^{\circ} 33^{\prime} 39^{\prime \prime} \mathrm{W}$ ). This WWTP is responsible for treatment of $22 \%$ of the city's total wastewater, serving 36,000 inhabitants. The volume of treated sewage corresponds to $180,645 \mathrm{~m}^{3}$ per month, generating a total of $113.53 \mathrm{t}$ of anaerobic SS per month.

After sampling, the SS samples were mixed with a reference soil collected in the Experimental Garden of the University of São Paulo State-UNESP (Campus Rio Claro, São Paulo, Brazil) in proportions of 10,25 and $50 \%$ SS (0.5 geometric progression from $100 \%$ SS). This soil was characterized based on its granulometry, organic matter content and electrical conductivity (Table 1).

\subsection{Detoxification of SS through monitored natural attenuation}

Samples of $100 \%$ SS and associations containing 10, 25 and $50 \%$ SS in soil were placed in individual plastic bags $(42.5 \times 65.0 \mathrm{~cm})$ that were micro-perforated with openings that were $0.5 \mathrm{~mm}$ in diameter and $1 \mathrm{~cm}$ apart. Each bag contained $8 \mathrm{~kg}$ of each sample. The bags were buried in the external area of the Experimental Garden of UNESP in Rio Claro (São Paulo, Brazil) in holes with a maximum depth of $50 \mathrm{~cm}$ to allow interactions between the samples and the external environment, besides avoid significant temperature variations. The Experimental Garden is a reference site to conduct this kind of experiment, because it is considered free of contaminants, which avoids the contamination of the samples. Moreover, the Experimental Garden is also an isolated place, which prevents the dispersion of contaminants to other environments. The experiment was conducted in duplicate over periods of 2,6 and 12 months, after which bioassays were carried out.

\subsection{Production of aqueous extracts (solubilized)}

Aqueous extracts of each fresh sample were obtained following the protocol proposed by ABNT NBR 10.006 (2004), using a suspension of $125 \mathrm{~g}$ of each sample (equivalent dry weight) in $500 \mathrm{~mL}$ of ultrapure water, followed by constant stirring at low speed for $5 \mathrm{~min}$. For samples of $100 \%$ SS, twice that amount of water was added $(1000 \mathrm{~mL})$. After 7 days of decantation at $22^{\circ} \mathrm{C}$, the liquid phase of the sample/water mixture was collected and filtered through a $0.45 \mathrm{~mm}$-pore-size membrane to obtain extracts containing water-soluble substances.

To obtain the equivalent dry weight, 3 independent aliquots of each sample $(10 \mathrm{~g})$ were dried at $105^{\circ} \mathrm{C}$ and weighed until a stable dry weight was obtained (approximately $24 \mathrm{~h}$ ). The average of each triplicate was considered as the equivalent dry weight of each sample and this value was used to prepare the aqueous extract.

\subsection{Chemical analysis}

After each period of monitored natural attenuation, chemical analysis of $100 \%$ SS solid samples was performed at the laboratory of the Analytical Technology Company (São Paulo-Brazil). The analyses were conducted according to the procedure described by USEPA SW-846 (1999b). The selection of the analyzed parameters were based on CONAMA resolution (National Environment Council) no. 375 (Ministério do Meio Ambiente, Conselho Nacional do Meio Ambiente, 2006), which determines the maximum limits of pollutants present in SS samples to allow their use in agricultural soils in Brazil.

The presence of volatile organic compounds (1,2,3-trichlorobenzene; 1,3,5-trichlorobenzene; 1,2,4-trichlorobenzene; 1,2dichlorobenzene) and semivolatile organic compounds (1,3-dichlorobenzene; 1,4-dichlorobenzene; 1,2,3,4-tetrachlorobenzene; 1,2,4,5-tetrachlorobenzene; 1,2,3,5-tetrachlorobenzene; di- $N$-butyl phthalate; dimethyl phthalate; 2,4-dichlorophenol; 2,4,6trichlorophenol; pentachlorophenol; benzo(a)anthracene; benzo (a)pyrene; benzo( $k$ )fluoranthene; indeno(1,2,3-cd)pyrene; naphthalene; phenanthrene; hexachlorobenzene; $m$ - and $p$-cresol; o-cresol; bis(2-ethylhexyl)phthalate) were quantified using gas chromatography-mass spectrometry (GC/MS), following the methods 8260B and 8270D (USEPA, 1999b), respectively.

The presence of organochlorine pesticides (heptachlor; aldrin; g-BHC; $a$-chlordane; g-chlordane; dieldrin; DDT; endrin; toxaphene; mirex) and inorganic compounds (phosphorus; potassium; sodium; sulfur; calcium; magnesium; arsenic; barium; cadmium; lead; copper; chrome; mercury; molybdenum; nickel; zinc) was analyzed using gas chromatography (GC), following the method 8081B (USEPA, 1999b) and inductively coupled 
Table 1

Granulometric analysis and electrical conductivity of the reference soil.

\begin{tabular}{|c|c|c|c|c|c|c|c|c|c|c|c|c|}
\hline Sample & Sand & $\mathrm{g} / \mathrm{kg}$ & & & & & Silt $(\mathrm{g} / \mathrm{kg})$ & Clay $(\mathrm{g} / \mathrm{kg})$ & & Flocculation $^{\mathrm{h}}(\%)$ & Texture class & Electrical conductivity $(\mu \mathrm{S} / \mathrm{cm})$ \\
\hline \multirow[t]{2}{*}{ Soil } & $\mathrm{VC}^{\mathrm{a}}$ & $\mathrm{C}^{\mathrm{b}}$ & $\mathrm{I}^{\mathrm{C}}$ & $\mathrm{T}^{\mathrm{d}}$ & $\mathrm{VT}^{\mathrm{e}}$ & $\mathrm{TS}^{\mathrm{f}}$ & 79 & w/disp. ${ }^{g}$ & water & 78 & Clayey & 146.7 \\
\hline & & 6 & 16 & 119 & 257 & 72 & & 469 & 451 & 100 & & \\
\hline
\end{tabular}

a Very coarse.

b Coarse.

c Intermediate.

d Thin.

e Very thin.

f Total sand.

g With dispersant.

h Proportion of clay that is flocculated, reporting on the degree of aggregate stability.

plasma-atomic emission spectrometry (method 6010C-USEPA, 1999b), respectively.

Dioxins and furans were quantified using high-resolution gas chromatography/high-resolution mass spectrometry (HRGC/ HRMS) by the method 8290A (USEPA, 1999b).

The identification of the compounds detected in the raw $100 \%$ SS samples were also performed in the aqueous SS extract at the laboratory of the Global Analysis and Consultancy (São Carlos-Brazil) following the method proposed by Opeolu et al. (2010) using high performance liquid chromatography with diode array detection (HPLC-DAD).

\subsection{Identification and quantification of microorganisms}

To identify the microorganisms present in the SS and the soil, $1 \mathrm{~g}$ of each sample (100\% SS or soil control) was added to $100 \mathrm{~mL}$ of sterile saline solution after each period of monitored natural attenuation. To assess the diversity of the microorganisms in the samples, $10 \mu \mathrm{L}$ of this solution was seeded by depletion, using a laboratory loop, into Petri dishes containing blood agar, MacConkey agar, SS agar and Sabouraud agar. The plates were incubated at $35^{\circ} \mathrm{C}$, except for the Sabouraud agar plates, which were kept at room temperature. The plates were read every $24 \mathrm{~h}$ for 7 days. The various microorganisms found in the samples were isolated and initially identified using conventional biochemical tests. These microorganisms were subsequently identified using automated Vitek 2 Compact equipment (BioMerieux ${ }^{\circledR}$, Inc, St Louis, MO, USA).

Microorganisms were quantified by scoring colony-forming units (CFUs).

\subsection{Bioassays with A. cepa seeds}

Seeds of $A$. cepa ( $2 n=16$ chromosomes) from the same lot and variety (the "Baia Periforme" onion) were submitted to germination in individual Petri dishes containing: $1-\mathrm{SS} /$ soil associations or $100 \%$ SS; or 2-aqueous extracts obtained from SS/soil associations or $100 \% \mathrm{SS}$, obtained both before and after the monitored natural attenuation process.

Controls were performed with ultrapure water (negative control), the aqueous extract of the reference soil, the reference soil itself (soil control) and $10 \mathrm{mg} / \mathrm{L}$ of methyl methane sulfonate (Sigma-Aldrich, CAS 66-27-3) (positive control). All tests were performed in duplicate.

After germination, onion roots $c a .2 .0 \mathrm{~cm}$ in length were collected and fixed in a mixture of ethanol and acetic acid $(3: 1-\mathrm{v} / \mathrm{v})$ for 6 to $18 \mathrm{~h}$ at room temperature. After this period, the roots were stored in freshly made fixation solution at $4{ }^{\circ} \mathrm{C}$ until use. The protocol described by Leme and Marin-Morales (2008) was followed to prepare slides of the meristematic and $\mathrm{F} 1$ root regions.

Genotoxic endpoints were estimated in meristematic cells of A. cepa that presented different types of chromosomal aberrations (e.g., losses, bridges, delays, adherence) and nuclear abnormalities (e.g., budding, binucleated cells, lobulated nuclei). Cytotoxicity was assessed through recording the changes in the mitotic index of these cells, and the mutagenic potential was assessed through recording the presence of micronuclei in meristematic and F1 cells and chromosomal breaks in meristematic cells.

These parameters were evaluated under a light microscope, and 10 slides per treatment were taken, and 500 cells were examined per slide.

The efficiency of the monitored natural attenuation was evaluated by comparing the results obtained in 5 individuals for each sample in each period tested to the negative control using the Mann-Whitney test $(p<0.05)$, as suggested by Caritá and MarinMorales (2008), Mazzeo et al. (2011), Christofoletti et al. (2012), Miranda et al. (2013), Mazzeo and Marin-Morales (2015).

\section{Results and discussion}

\subsection{Chemical analysis}

Detailed results of the chemical analyses performed in the raw $100 \%$ SS during the different periods of natural attenuation as well as in the soil used to prepare the soil/SS associations can be found in the Supplementary data (Table S1).

A major concern regarding the application of SS to agricultural soils is related to the presence of high levels of metals in SS, which can negatively impact the soil. Once metals are added to the soil, it is very difficult to remove them due to their mobility and residual time, which leads to long-term interference with soil proprieties and, hence, with the quality of agricultural crops (Jiang and Fan, 2008). Moreover, unlike organic contaminants, most metals are not affected by microbial or chemical degradation (Park et al., 2011) and therefore require more specific technologies for their removal from the environment.

In this study, the metal concentrations recorded in the SS from the Rio Claro WWTP were below the limits established by CONAMA 375 (Ministério do Meio Ambiente, Conselho Nacional do Meio Ambiente, 2006-(Table S1)), which characterize this material as a potential fertilizer for agricultural soils.

The results of the chemical analysis indicated the presence of $m$ and $p$-cresol at concentrations that were much higher than those established by legislation (Ministério do Meio Ambiente, Conselho Nacional do Meio Ambiente, 2006) in both the initial SS and the SS degraded for 2 months (Table 2). These substances were also detected at high concentrations in the aqueous SS extracts at the 0 - and 2-month sampling times (Table 2).

Cresols are substances belonging to a chemical group of phenolic compounds that are employed in several industrial processes (ATSDR, 2008; Sen et al., 2014). $m$-Cresol and $p$-cresol are used in the production of contact herbicides, pyrethroid insecticides, fragrances, antioxidants, flame-retardants, synthetic resins, disinfectants and explosives, among other products (OECD, 2003; ATSDR, 2008; Tallur et al., 2009). According to Arya et al. (2011), 
Table 2

Quantification of $m$ - and $p$-cresol in SS following different periods of monitored natural attenuation.

\begin{tabular}{|c|c|c|c|c|c|c|}
\hline Parameter & Material & Unit & Initial sample & 2-Month sample & 6-Month sample & 12-Month sample \\
\hline \multirow[t]{2}{*}{$m-, p$-Cresol } & Raw sludge & $\mu \mathrm{g} / \mathrm{kg}$ & $276,089.8$ & $256,743.4$ & $\mathrm{ND}^{\mathrm{a}}$ & $\mathrm{ND}^{\mathrm{a}}$ \\
\hline & Aqueous extract & $\mathrm{mg} / \mathrm{L}$ & 3.70 & 4.21 & $0.78(81.47 \%)^{\mathrm{b}}$ & $0.06(98.58 \%)^{b}$ \\
\hline
\end{tabular}

a Not detected.

b Percent decrease in $m$ - and $p$-cresol concentrations.

these substances are also present in effluents from the textile, pulp and paper, coal conversion and fungicide industries. Furthermore, isomeric cresols are widely distributed in nature and naturally present in the oils of some plants (e.g., jasmine, cinnamon, mint, eucalyptus, conifers and camphor), petroleum, coal tar and geological materials from volcanic eruptions, in addition to often being produced by soil microorganisms as intermediary metabolites during biodegradation (IPCS, 1995). Thus, cresols reach the environment either through natural sources or via the combustion of coal and wood, vehicle exhaust, oil refineries and even cigarette smoke (ATSDR, 2008). Bright and Healey (2003) detected the presence of $m$ - and $p$-cresol in SSs from five WWTPs in the metropolitan area of Vancouver (Canada) at concentrations ranging from 0.46 to $940 \mu \mathrm{g} / \mathrm{g}$, with the highest concentration exceeding the limits allowed for the use of SS in soils. In a review, Harrison et al. (2006) also described studies identifying the presence of methylphenol in SS at concentrations up to $1160 \mathrm{mg} / \mathrm{kg}$ dry weight.

Evaluation of the natural attenuation process applied in this study demonstrated that after 6 months, $m$ - and $p$-cresol were no longer present in the raw SS samples (at 6 and 12 months), at least at concentrations that were detectable by the methods used in our chemical analysis, indicating degradation of these compounds.

Dioxins (polychlorinated dibenzo-p-dioxins-PCDDs) and furans (polychlorinated dibenzofurans-PCDFs) were also detected in the studied samples (Table 3). According to Kulkarni et al. (2008) and Suzuki et al. (2011), the presence of dioxins and furans in the environment occurs mainly as a result of anthropogenic activities related to the incineration of solid domestic and hospital wastes; the combustion of diesel, wood and coal; industrial activities such as pulp bleaching; steel mills; the manufacture of pesticides and the incineration of halogenic material; and the action of microorganisms and photochemical reactions of certain substances. The presence of dioxins and furans in SS was also reported by Klimm et al. (1998).

The Brazilian government does not set limits for these substances in SS to be used in agricultural soil. However, Canadian legislation establishes thresholds for agricultural soils ranging from 17 to $50 \mathrm{ng} \mathrm{TEQ} / \mathrm{kg}$ dry weight of SS and a limit for non-agricultural soils of up to $100 \mathrm{ng}$ TEQ/kg dry weight of SS (Leblanc et al., 2008). In the present study, the chemical analyses showed an increase in the dioxin and furan concentration in the $100 \%$ SS along the natural attenuation period (Table 3 ).

Based on these results, it is possible to conclude that the increase of these substances may be related to the decrease in the total mass of SS during the natural attenuation process and the consequent mineralization of organic matter (loss of total organic carbon-Table S1) without the decrement of dioxins and furans, resulting in higher final concentrations of these substances. Another evidence for supporting this explanation is that the same increase of the metal levels was also observed. According to Matamoros et al. (2012), the dewatering and mineralization of organic matter of SS lead to a higher metal concentration in this matrix. In the present study, mineralization is more likely explanation because of the fact that the concentrations are expressed on a dry basis.

Another explanation is that the presence of these substances may be related to microbial degradation of compounds not identified in the chemical analysis, e.g. chlorinated biphenyls (PCBs), that

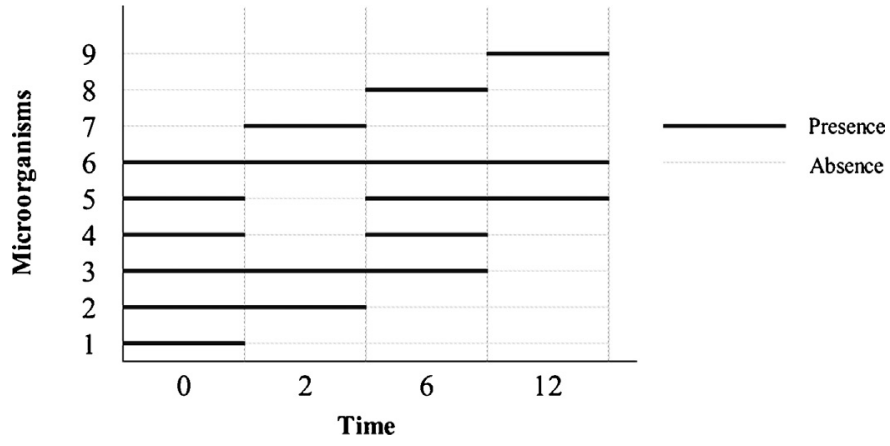

Fig. 1. Microbiological succession observed during the monitored natural attenuation of SS. (1) Enterococcus faecalis, Escherichia coli, Klebsiella pneumoniae, Staphylococcus (coagulase-negative); (2) Morganella morganii, Proteus mirabilis; (3) Enterobacter cloacae; (4) Pseudomonas aeruginosa; (5) Serratia marcescens; (6) Bacillus sp.; (7) Gram-negative bacilli (non-fermenter), Providencia rettgeri; (8) Citrobacter freundii, Ochrobactrum anthropi; (9) Achromobacter denitrificans, Burkholderia cepacia complex, Buttiauxella agrestis, Pseudomonas putida/fluorescens.

can be transformed in dioxins and furans as observed in the study conducted by Weber et al. (2002).

Although there were increases in the amounts of dioxins and furans during the attenuation period, according to the indexes provided by Canadian legislation, the results are not alarming because they are below $17 \mathrm{ng}$ I-TEQ/kg dry weight SS.

The chemical analysis performed on the SS samples that had been buried for 2 months revealed a new substance (bis(2ethylhexyl)phthalate) that was not present in the analysis of the initial SS. This substance is a synthetic plasticizer that exhibits high stability, fluidity and low volatility and is widely added to plastics to make them more flexible, specifically those composed of polyvinyl chloride (PVC) (Carrara et al., 2011). Because this substance was not detected in the initial chemical analysis, we suggest that its presence in the SS sample attenuated for 2 months was resulted of the transfer of this compound from the plastic bag to the samples. However, this substance was not detected in the subsequent chemical analyses performed on the SS samples buried for 6 and 12 months (Table S1). Therefore, we conclude that the release of phthalate occurred during the first contact of the samples with the plastic material, which most likely occurred until the second month of the experiment. After this period, we believe that the phthalate had been depleted from the plastic bag and was degraded.

\subsection{Microbiological characterization of SS}

The results of the microbiological characterization of the SS after the tested attenuation periods and the reference soil are presented in Table 4.

Regarding the reference soil sample, a low diversity of microorganisms was recorded. For the SS samples, we observed a change in the microbial composition of the samples (Fig. 1) involving 17 different genera of bacteria along the different periods of natural attenuation. The presence of Gram-positive cocci (Enterococcus faecalis and Staphylococcus (coagulase-negative)) was exclusively observed in the initial sample. Enterobacteria (Citrobacter freundii, Enterobacter cloacae, Escherichia coli, Klebsiella pneumoniae, Morganella morganii, Proteus mirabilis and 
Table 3

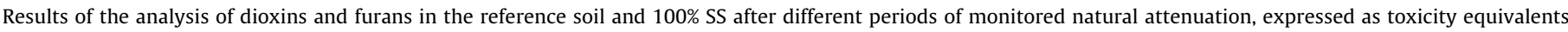
(TEQs), based on toxic equivalent factors (W-TEFs) for 2005 established by the World Health Organization (WHO).

\begin{tabular}{|c|c|c|c|c|c|c|}
\hline Dioxins & Reference soil & Initial sample & 2-Month sample & 6-Month sample & 12-Month sample & TEF \\
\hline & $\mathrm{W}$-TEQ $(\mathrm{ng} / \mathrm{kg})$ & W-TEQ (ng/kg) & W-TEQ (ng/kg) & W-TEQ (ng/kg) & W-TEQ (ng/kg) & W-TEF \\
\hline $2,3,7,8-\mathrm{TCDD}$ & $\mathrm{ND}^{\mathrm{a}}$ & $\mathrm{ND}^{\mathrm{a}}$ & 0.9423 & $\mathrm{ND}^{\mathrm{a}}$ & 0.42 & 1 \\
\hline 1,2,3,7,8-PeCDD & 0.2140 & 1.654 & 1.873 & $\mathrm{ND}^{\mathrm{a}}$ & 2.56 & 1 \\
\hline $1,2,3,4,7,8-\mathrm{HxCDD}$ & $\mathrm{ND}^{\mathrm{a}}$ & $\mathrm{ND}^{\mathrm{a}}$ & 0.0619 & $\mathrm{ND}^{\mathrm{a}}$ & 0.499 & 0.1 \\
\hline $1,2,3,6,7,8-\mathrm{HxCDD}$ & 0.03774 & 0.2513 & 0.4148 & 5.296 & 1.76 & 0.1 \\
\hline 1,2,3,7,8,9-HxCDD & 0.03071 & $\mathrm{ND}^{\mathrm{a}}$ & 0.1377 & $\mathrm{ND}^{\mathrm{a}}$ & 0.093 & 0.1 \\
\hline $1,2,3,4,6,7,8-\mathrm{HpCDD}$ & 0.1199 & 0.3187 & 0.7052 & 1.678 & 1.86 & 0.01 \\
\hline OCDD & 0.01778 & 0.06996 & 0.16302 & 0.19902 & 0.2289 & 0.0003 \\
\hline Total dioxin TEQs & 0.42013 & 2.29396 & 4.29792 & 7.17302 & 7.4209 & \\
\hline \multicolumn{7}{|l|}{ Furans } \\
\hline $2,3,7,8-\mathrm{TCDF}$ & 0.02031 & 0.2105 & 0.2503 & $\mathrm{ND}^{\mathrm{a}}$ & 0.411 & 0.1 \\
\hline 1,2,3,7,8-PeCDF & 0.00659 & $\mathrm{ND}^{\mathrm{a}}$ & 0.06858 & $\mathrm{ND}^{\mathrm{a}}$ & 0.0804 & 0.03 \\
\hline $2,3,4,7,8-\mathrm{PeCDF}$ & 0.10311 & 0.8442 & 0.7677 & $\mathrm{ND}^{\mathrm{a}}$ & 0.627 & 0.3 \\
\hline $1,2,3,4,7,8-\mathrm{HxCDF}$ & 0.02150 & 0.2610 & 0.3212 & $\mathrm{ND}^{\mathrm{a}}$ & 0.293 & 0.1 \\
\hline $1,2,3,6,7,8-\mathrm{HxCDF}$ & 0.01535 & 0.1461 & 0.2531 & $\mathrm{ND}^{\mathrm{a}}$ & $\mathrm{ND}^{\mathrm{a}}$ & 0.1 \\
\hline $2,3,4,6,7,8-\mathrm{HxCDF}$ & 0.01476 & 0.1665 & 0.2353 & $\mathrm{ND}^{\mathrm{a}}$ & 0.304 & 0.1 \\
\hline $1,2,3,7,8,9-\mathrm{HxCDF}$ & 0.01753 & $\mathrm{ND}^{\mathrm{a}}$ & 0.04516 & $\mathrm{ND}^{\mathrm{a}}$ & 0.440 & 0.1 \\
\hline $1,2,3,4,6,7,8-\mathrm{HpCDF}$ & 0.01196 & 0.2147 & 0.3251 & 0.3874 & 0.0171 & 0.01 \\
\hline $1,2,3,4,7,8,9-\mathrm{HpCDF}$ & $\mathrm{ND}^{\mathrm{a}}$ & $\mathrm{ND}^{\mathrm{a}}$ & 0.01193 & $\mathrm{ND}^{\mathrm{a}}$ & 0.491 & 0.01 \\
\hline OCDF & 0.00087 & 0.01273 & 0.02562 & 0.018876 & 0.02097 & 0.0003 \\
\hline Total furan TEQs & 0.21198 & 1.85573 & 2.30399 & 0.406276 & 2.68447 & \\
\hline General total TEQs & 0.63211 & 4.14969 & 6.60191 & 7.579296 & 10.10537 & \\
\hline
\end{tabular}

a Not detected.

Providencia rettgeri) predominated over the initial periods, remaining up to 6 months of natural attenuation. Non-fermenter Gram-negative bacilli (Achromobacter denitrificans, Burkholderia cepacia complex and Pseudomonas fluorescens/putida) and fungus were observed, predominantly, in samples from 12 months of attenuation. The only species presented in all of the analyzed samples was Bacillus sp. Petersen et al. (2003) also reported a microbial succession during the sewage sludge decomposition, as observed in the present study.

During the attenuation process, a decrease in the final counting of total bacteria was also observed for the final period (below $5 \times 10^{5}$ ). Thus, both the alteration in the groups of microbial community and the counting of total bacteria in SS can be used as indicators of each step of the natural attenuation process.
Several studies suggest that some of the microorganisms identified in the investigated SS may have the ability to degrade substances that were initially present in these samples. Among them, the bacteria Pseudomonas sp. (Saravanan et al., 2008; Ho et al., 2010); Bacillus sp. (Tallur et al., 2006; Tallur et al., 2009; Ho et al., 2010); Serratia liquefaciens (Sharma et al., 2002); Serratia plymuthica (Pradhan and Ingle, 2007); Serratia marcescens (Singh et al., 2007); P. mirabilis (Mohite et al., 2011) were cited in the literature as efficient species in the mineralization of phenolic derivatives, including cresol. According to our results, only the bacteria Bacillus sp., E. cloacae, $P$. rettgeri, $M$. morganii, $P$. mirabilis and non-fermenter Gram-negative bacilli can be inferred to be possible agents for the degradation of phenols present in the SS studied here, since Pseudomonas aeruginosa and Serratia sp., recognized

Table 4

Characterization of microorganisms isolated from SS after different periods of monitored natural attenuation.

\begin{tabular}{|c|c|c|c|c|c|}
\hline Microorganisms & Reference soil & Initial sample & 2-Month sample & 6-Month sample & 12-Month sample \\
\hline \multicolumn{6}{|l|}{ Bacteria } \\
\hline Achromobacter denitrificans ${ }^{\mathrm{a}}$ & - & - & - & - & $2 \times 10^{4}$ \\
\hline Bacillus sp. ${ }^{\mathrm{b}}$ & $4 \times 10^{5}$ & $10^{7}$ & $4 \times 10^{5}$ & $10^{5}$ & $5 \times 10^{5}$ \\
\hline Burkholderia cepacia complex ${ }^{\mathrm{a}}$ & - & - & - & - & $3 \times 10^{5}$ \\
\hline Buttiauxella agrestis $^{\mathrm{a}}$ & - & - & - & - & $3 \times 10^{5}$ \\
\hline Citrobacter freundii $^{\mathrm{a}}$ & - & - & - & $10^{7}$ & - \\
\hline Enterobacter cloacae $^{\mathrm{a}}$ & - & $8 \times 10^{6}$ & $4 \times 10^{5}$ & $10^{7}$ & - \\
\hline Enterococcus faecalis ${ }^{\mathrm{b}}$ & - & $5 \times 10^{6}$ & - & - & - \\
\hline Escherichia coli $^{\mathrm{a}}$ & - & $9 \times 10^{6}$ & - & - & - \\
\hline Klebsiella pneumoniae $^{\mathrm{a}}$ & - & $10^{7}$ & - & - & - \\
\hline Morganella morganii & - & $10^{7}$ & $10^{5}$ & - & - \\
\hline Ochrobactrum anthropi $i^{\mathrm{a}}$ & - & - & - & $10^{4}$ & - \\
\hline Proteus mirabilis ${ }^{\mathrm{a}}$ & - & $9 \times 10^{6}$ & $3 \times 10^{6}$ & - & - \\
\hline Providencia rettgeri $^{\mathrm{a}}$ & - & - & $3 \times 10^{5}$ & - & - \\
\hline Pseudomonas aeruginosa ${ }^{\mathrm{a}}$ & - & $8 \times 10^{6}$ & - & $2.2 \times 10^{6}$ & - \\
\hline Pseudomonas putida/fluorescens ${ }^{\mathrm{a}}$ & - & - & - & - & $10^{4}$ \\
\hline Serratia marcescens ${ }^{\mathrm{a}}$ & - & $10^{7}$ & - & $10^{7}$ & $10^{4}$ \\
\hline Staphylococcus ${ }^{\mathrm{b}}$ (coagulase-negative) & - & $10^{6}$ & - & - & - \\
\hline Gram negative bacillia (non-fermenter) & - & - & $1 \times 10^{6}$ & - & - \\
\hline \multicolumn{6}{|l|}{ Fungus } \\
\hline Penicillium sp. & $5 \times 10^{4}$ & - & - & - & $10^{6}$ \\
\hline
\end{tabular}

\footnotetext{
a Gram negative.
}

b Gram positive. 
Table 5

Alterations in cells of A. cepa exposed to various concentrations of raw SS after different periods of natural attenuation.

\begin{tabular}{|c|c|c|c|c|c|c|c|c|}
\hline \multirow{2}{*}{$\begin{array}{l}\text { Evaluated } \\
\text { parameters }\end{array}$} & \multirow{2}{*}{$\begin{array}{l}\text { MNA }^{\text {a }} \\
\text { (months) }\end{array}$} & \multicolumn{7}{|l|}{ Samples } \\
\hline & & Soil & $\mathrm{NC}^{\mathrm{b}}$ & $\mathrm{PC}^{\mathrm{C}}$ & $10 \% \mathrm{SS}$ & $25 \% \mathrm{SS}$ & $50 \%$ SS & $100 \%$ SS \\
\hline \multirow{4}{*}{ Mitotic Index } & 0 & $42.17 \pm 7.23$ & $34.88 \pm 13.40$ & $36.03 \pm 9.02$ & $41.78 \pm 8.61$ & $43.04 \pm 6.62$ & $44.21 \pm 12.93$ & $40.78 \pm 8.24$ \\
\hline & 2 & & $34.11 \pm 5.09$ & $38.08 \pm 5.05$ & $37.50 \pm 10.01$ & $37.95 \pm 5.30$ & $35.24 \pm 5.68$ & - \\
\hline & 6 & & $46.17 \pm 8.25$ & $44.73 \pm 5.09$ & $39.93 \pm 7.56$ & $39.71 \pm 7.58$ & $42.39 \pm 5.66$ & $34.22 \pm 6.51^{*}$ \\
\hline & 12 & & $45.87 \pm 6.76$ & $49.03 \pm 9.88$ & $42.84 \pm 7.71$ & $40.40 \pm 10.36$ & $48.08 \pm 7.46$ & $44.58 \pm 12.92$ \\
\hline \multirow{4}{*}{$\begin{array}{l}\text { Genotoxic } \\
\text { alterations }\end{array}$} & 0 & $5.36 \pm 1.88$ & $2.20 \pm 1.29$ & $8.78 \pm 1.47^{*}$ & $6.58 \pm 1.73^{*}$ & $10.13 \pm 2.62^{*}$ & $14.44 \pm 3.70^{*}$ & $16.82 \pm 3.08^{*}$ \\
\hline & 2 & & $3.73 \pm 1.51$ & $10.35 \pm 1.65^{*}$ & $9.37 \pm 3.60$ & $12.88 \pm 5.27^{*}$ & $11.69 \pm 3.70^{*}$ & - \\
\hline & 6 & & $4.89 \pm 2.28$ & $14.30 \pm 5.14$ & $5.99 \pm 3.15$ & $7.39 \pm 2.10^{*}$ & $7.00 \pm 1.85^{*}$ & $10.60 \pm 4.13^{*}$ \\
\hline & 12 & & $2.07 \pm 1.42$ & $10.72 \pm 2.84$ & $1.81 \pm 0.84$ & $2.30 \pm 1.14$ & $1.42 \pm 1.65$ & $3.38 \pm 1.75$ \\
\hline \multirow{4}{*}{$\begin{array}{l}\text { Mutagenic } \\
\text { alterations }\end{array}$} & 0 & $0.59 \pm 0.69$ & $0.48 \pm 0.68$ & $16.71 \pm 6.22^{*}$ & $0.88 \pm 0.56$ & $1.28 \pm 1.32$ & $0.98 \pm 0.80$ & $1.28 \pm 1.32$ \\
\hline & 2 & & $0.00 \pm 0.00$ & $10.62 \pm 6.12^{*}$ & $0.49 \pm 0.51$ & $2.27 \pm 2.71^{*}$ & $1.65 \pm 1.71^{*}$ & - \\
\hline & 6 & & $0.79 \pm 0.62$ & $6.67 \pm 3.32^{*}$ & $0.69 \pm 0.67$ & $1.52 \pm 1.19$ & $1.00 \pm 1.25$ & $2.22 \pm 1.55^{*}$ \\
\hline & 12 & & $020 \pm 0.41$ & $12.34 \pm 4.45^{*}$ & $0.57 \pm 0.49$ & $0.28 \pm 0.46$ & $0.57 \pm 0.49$ & $0.38 \pm 0.49$ \\
\hline \multirow[t]{4}{*}{$\mathrm{MN} \mathrm{F}^{\mathrm{d}}$} & 0 & $0.58 \pm 0.68$ & $0.38 \pm 0.49$ & $8.63 \pm 6.80^{*}$ & $0.09 \pm 0.29$ & $0.29 \pm 0.66$ & $0.00 \pm 0.00$ & $0.19 \pm 0.39$ \\
\hline & 2 & & $0.78 \pm 0.62$ & $8.83 \pm 5.44^{*}$ & $0.29 \pm 0.65$ & $0.30 \pm 0.67$ & $1.36 \pm 0.51$ & - \\
\hline & 6 & & $0.59 \pm 0.68$ & $8.09 \pm 5.14^{*}$ & $0.39 \pm 0.69$ & $0.78 \pm 0.77$ & $1.27 \pm 1.30$ & $3.81 \pm 4.73^{*}$ \\
\hline & 12 & & $0.39 \pm 0.51$ & $10.57 \pm 4.28^{*}$ & $0.97 \pm 1.22$ & $0.20 \pm 0.42$ & $0.86 \pm 2.09$ & $0.58 \pm 0.68$ \\
\hline
\end{tabular}

a Monitored natural attenuation.

b Negative control.

c Positive control.

d Micronuclei in F1 cells.

Significantly different from the negative control $(p<0.05)$ according to the Mann-Whitney test.

as potential degradation agents for this type of waste, were not present at 2 months of natural attenuation and these compounds did not persist beyond this time (Fig. 1).

Species of the genus Bacillus (Juneson et al., 2001; Niazi et al., 2001; Azarova et al., 2003; Yuan et al., 2010) and Pseudomonas (Azarova et al., 2003) are recognized as bacteria with the potential to degrade phthalates. Our data also suggest that the genus Bacillus is effective in the degradation of bis(2-ethylhexyl)phthalate. However, we also observed the involvement of the bacteria $E$. cloacae, $P$. rettgeri, $M$. morganii, $P$. mirabilis and non-fermenter Gram-negative bacilli in the biodegradation of phthalates.

Even though several microorganisms have been described as degraders of dioxin and furan, including Pseudomonas sp. HH69 (Fortnagel et al., 1990), Sphingomonas sp. RW1 (Wilkes et al., 1996), Burkholderia JB1 (Parsons et al., 1998), Terrabacter sp. (Habe et al., 2002) and Geobacillus sp. UZO 3 (Suzuki et al., 2011), in the present study, under the conditions employed in our tests, none of the identified microorganisms appeared to be capable of degrading dioxins and furans, as there were increases in these compounds during the attenuation process.

\subsection{Evaluation of the effects of SS on the test organism A. cepa}

Tables 5 and 6 present results related to the effect of the studied SS on the test $\operatorname{organism}$ A. cepa.

The aqueous extract of the $100 \%$ SS at 0 and 2 months and the raw $100 \%$ SS at 2 months were considered highly toxic to the test organism, completely inhibiting seed germination, thus precluding the evaluation of the cytotoxic, genotoxic and mutagenic potential of these samples. Similar results were recorded by Walter et al. (2006) regarding the germination of cress seeds (Lepidium sativum $\mathrm{L}$.) exposed to SS processed obtained following anaerobic

Table 6

Alterations in cells of A. cepa exposed to various concentrations of aqueous SS extracts (solubilized) after different periods of natural attenuation.

\begin{tabular}{|c|c|c|c|c|c|c|c|c|}
\hline \multirow{2}{*}{$\begin{array}{l}\text { Evaluated } \\
\text { parameters }\end{array}$} & \multirow{2}{*}{$\begin{array}{l}\text { MNA }^{\mathrm{a}} \\
\text { (months) }\end{array}$} & \multicolumn{7}{|l|}{ Samples } \\
\hline & & Soil & $\mathrm{NC}^{\mathrm{b}}$ & $\mathrm{PC}^{\mathrm{c}}$ & $10 \%$ SS & $25 \% \mathrm{SS}$ & $50 \%$ SS & $100 \% \mathrm{SS}$ \\
\hline Mitotic Index & $\begin{array}{l}0 \\
2 \\
6 \\
12\end{array}$ & $30.58 \pm 5.43$ & $\begin{array}{l}34.88 \pm 13.40 \\
34.11 \pm 5.09 \\
46.17 \pm 8.25 \\
45.87 \pm 6.76\end{array}$ & $\begin{array}{l}36.03 \pm 9.02 \\
38.08 \pm 5.05 \\
44.73 \pm 5.09 \\
49.03 \pm 9.88\end{array}$ & $\begin{array}{l}36.84 \pm 13.04 \\
35.71 \pm 7.59 \\
46.63 \pm 9.85 \\
48.86 \pm 2.99\end{array}$ & $\begin{array}{l}35.44 \pm 8.00 \\
36.61 \pm 7.11 \\
47.78 \pm 7.94 \\
50.84 \pm 7.38\end{array}$ & $\begin{array}{l}35.95 \pm 7.11 \\
35.71 \pm 13.12 \\
46.61 \pm 8.17 \\
51.05 \pm 6.49\end{array}$ & $\begin{array}{l}- \\
- \\
48.31 \pm 7.67 \\
47.14 \pm 5.48\end{array}$ \\
\hline $\begin{array}{l}\text { Genotoxic } \\
\text { alterations }\end{array}$ & $\begin{array}{l}0 \\
2 \\
6 \\
12\end{array}$ & $3.02 \pm 1.06$ & $\begin{array}{l}2.20 \pm 1.29 \\
3.73 \pm 1.51 \\
4.89 \pm 2.28 \\
2.07 \pm 1.42\end{array}$ & $\begin{array}{l}8.78 \pm 1.47^{*} \\
10.35 \pm 1.65^{*} \\
14.30 \pm 5.14^{*} \\
10.72 \pm 2.84^{*}\end{array}$ & $\begin{array}{l}4.34 \pm 1.62^{*} \\
5.69 \pm 1.85^{*} \\
4.95 \pm 2.15 \\
2.07 \pm 0.85\end{array}$ & $\begin{array}{l}8.00 \pm 1.98^{*} \\
9.59 \pm 3.79^{*} \\
9.09 \pm 2.58^{*} \\
1.34 \pm 1.02\end{array}$ & $\begin{array}{l}7.41 \pm 3.00^{*} \\
10.49 \pm 2.69^{*} \\
7.50 \pm 2.54^{*} \\
1.83 \pm 1.33\end{array}$ & $\begin{array}{l}- \\
- \\
10.19 \pm 3.32 \\
4.38 \pm 1.53^{*}\end{array}$ \\
\hline $\begin{array}{l}\text { Mutagenic } \\
\text { alterations }\end{array}$ & $\begin{array}{l}0 \\
2 \\
6 \\
12\end{array}$ & $0.55 \pm 0.89$ & $\begin{array}{l}0.48 \pm 0.68 \\
0.00 \pm 0.00 \\
0.79 \pm 0.62 \\
0.20 \pm 0.41\end{array}$ & $\begin{array}{l}16.71 \pm 6.22^{*} \\
10.62 \pm 6.12^{*} \\
6.67 \pm 3.32^{*} \\
12.34 \pm 4.45^{*}\end{array}$ & $\begin{array}{l}0.76 \pm 0.74 \\
0.38 \pm 0.67 \\
0.69 \pm 0.66 \\
0.55 \pm 0.64\end{array}$ & $\begin{array}{l}1.27 \pm 1.61 \\
2.67 \pm 2.57^{*} \\
1.06 \pm 1.13 \\
0.28 \pm 0.63\end{array}$ & $\begin{array}{l}1.45 \pm 1.23 \\
1.42 \pm 0.99^{*} \\
0.49 \pm 0.51 \\
0.37 \pm 0.63\end{array}$ & $\begin{array}{l}- \\
- \\
2.99 \pm 2.73^{*} \\
1.13 \pm 1.14^{*}\end{array}$ \\
\hline $\mathrm{MN} \mathrm{F}^{\mathrm{d}}$ & $\begin{array}{l}0 \\
2 \\
6 \\
12\end{array}$ & $0.47 \pm 0.80$ & $\begin{array}{l}0.38 \pm 0.49 \\
0.78 \pm 0.62 \\
0.59 \pm 0.68 \\
0.39 \pm 0.51\end{array}$ & $\begin{array}{l}8.63 \pm 6.80^{*} \\
8.83 \pm 5.44^{*} \\
8.09 \pm 5.14^{*} \\
10.57 \pm 4.28^{*}\end{array}$ & $\begin{array}{l}0.00 \pm 0.00 \\
1.56 \pm 0.84 \\
1.56 \pm 1.24 \\
1.17 \pm 0.77\end{array}$ & $\begin{array}{l}0.10 \pm 0.30 \\
3.65 \pm 3.68 \\
1.67 \pm 1.49 \\
0.78 \pm 0.78\end{array}$ & $\begin{array}{l}3.09 \pm 1.28 \\
2.25 \pm 1.21^{*} \\
1.48 \pm 1.07 \\
0.58 \pm 0.66\end{array}$ & $\begin{array}{l}- \\
- \\
3.53 \pm 4.53^{*} \\
0.88 \pm 0.72\end{array}$ \\
\hline
\end{tabular}

\footnotetext{
a Monitored natural attenuation.

b Negative control.

c Positive control.

d Micronuclei in F1 cells.

* Significantly different from the negative control $(p<0.05)$ according to the Mann-Whitney test.
} 

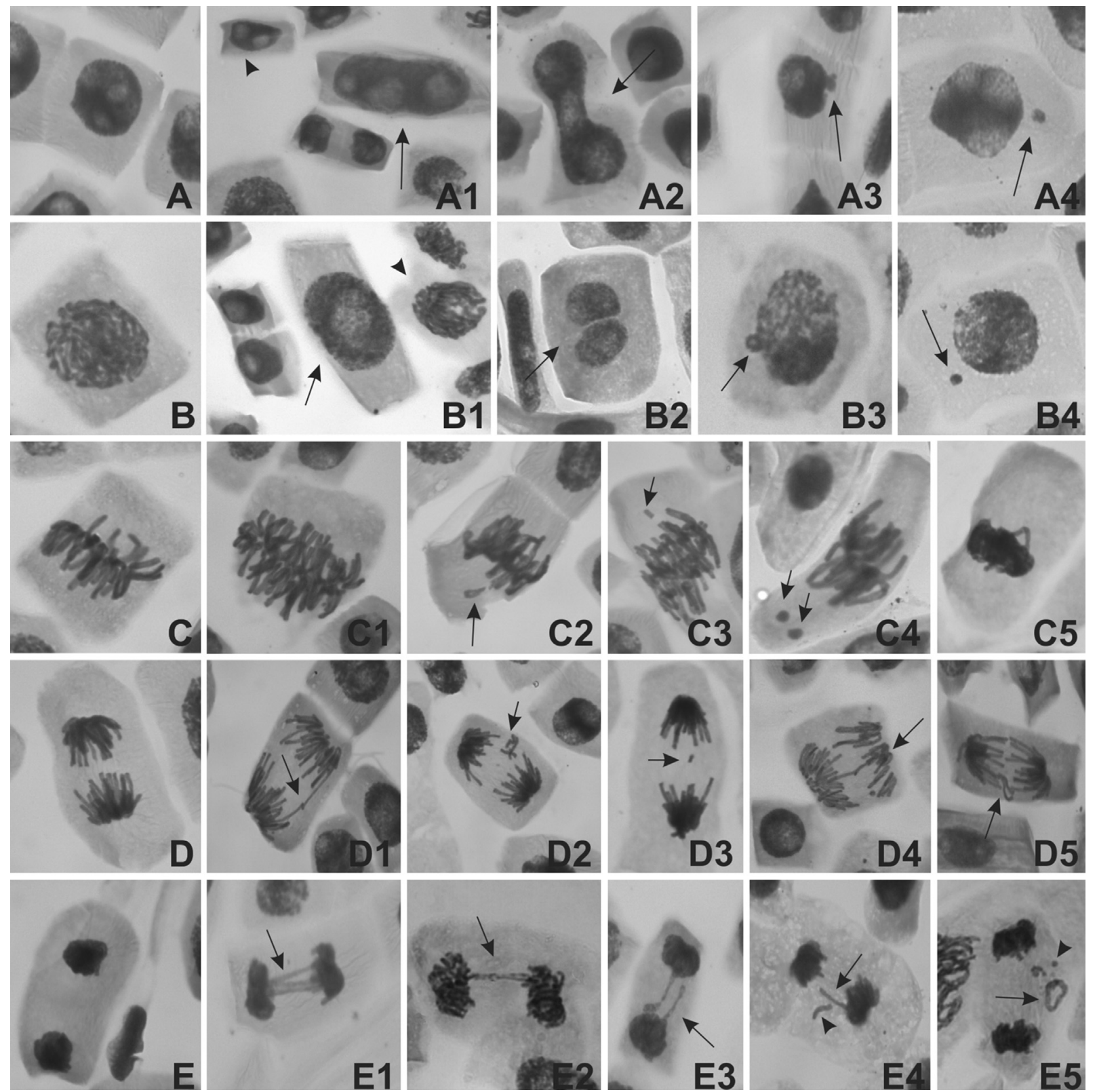

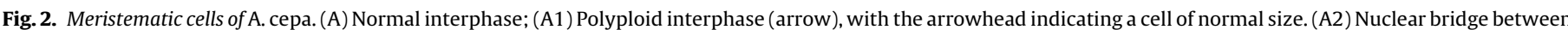

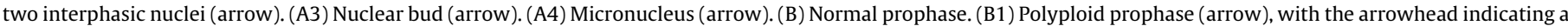

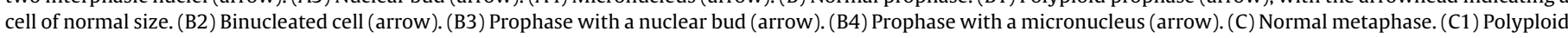

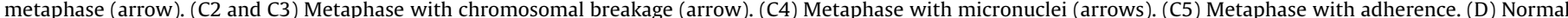

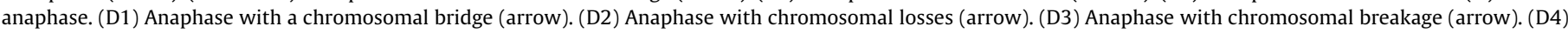

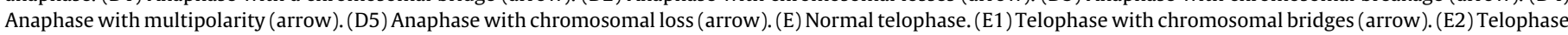

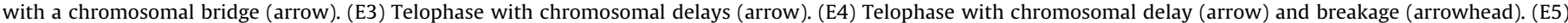
Telophase with chromosomal loss (arrow) and breakage (arrowhead).

digestion and thermal drying. In the present study, no inhibition of seed germination was observed for the other tested samples.

Evaluation of the cytotoxicity in seed germinated directly in SS after a period of 6 months indicated that at the $100 \%$ SS, mitotic cell division of $A$. cepa was inhibited (Table 5). However, after 12 months of natural attenuation, this effect was no longer observed. In the bioassays performed with aqueous extracts, no difference was observed in the mitotic index for the SS attenuated for 6 months (Table 6). These results indicate that the substances responsible for the observed cytotoxic effects are not transported by water because they were not present in the aqueous extract, and they may therefore have adhered to the particles of the SS itself and in this case, released during the decomposition of sludge. However, after 12 months of natural attenuation, these compounds were no longer present in the SS. These data show that the toxicity of the SS decreased during the period of natural attenuation of the SS samples, which confirms the efficiency of this process for the studied residue.

Concerning genotoxic effects, a significant frequency of cellular alterations was observed in association with SS concentrations of 10,25 and $50 \%$ after periods of 0 and 2 months and for concentrations of 25,50 and $100 \%$ of both raw SS and aqueous SS extracts after a period of 6 months (Fig. 2). However, the aqueous extracts induced a more severe genotoxic effect on the cells, as even after a period of 12 months, the $100 \%$ SS still induced significant genotoxic effects, indicating that substances with genotoxic potential 
are bioavailable in SS even after 12 months of natural attenuation. Our results regarding the genotoxic potential of the SS indicated that $100 \%$ SS cannot be considered a candidate material for use as a soil reconditioner due to its persistent toxicity observed in this study. Thus, based on the obtained results, soil/SS mixtures are more suitable for use in agriculture.

Regarding the mutagenic effect observed in meristematic cells of $A$. cepa, significant results were recorded for concentrations $25 \%$ and $50 \%$ SS after a period of 2 months and for $100 \%$ SS after a period of 6 months in both types of tests (raw SS and aqueous SS extract). For the aqueous extract, $100 \%$ SS after a period of 2 months also induced a significant frequency of micronuclei (Fig. 2A4, B4 and C4). The significant results recorded for F1 cells indicated that the damage observed in meristematic cells was transferred to and fixed in cells of the F1 region. Thus, even at lower concentrations, the SS samples were capable of inducing damage to the genetic material of the test organism. These data support the findings for other toxicity parameters evaluated here, as 100\% SS was difficult to detoxify compared with the soil/SS associations. Based on all of the results described above, it appears that a period of 12 months constitutes an excellent amount of time for the degradation of many mutagenic substances present in the studied SS.

Induction of genotoxic damage in A. cepa resulting from exposure to SS has also been reported by other authors, such as Srivastava et al. (2005), who observed a decrease in the mitotic index and a significant frequency of chromosomal aberrations induced by exposure to an aqueous extract of SS collected in a town in India. Aqueous extracts of SS from five WWTPs in the metropolitan area of São Paulo were also shown to induce genetic damage in A. cepa (Caritá, 2007). Furthermore, Christofoletti et al. (2012) observed a significant genotoxic effect in seeds of $A$. cepa exposed to raw biosolids from a municipality of São Paulo State (Brazil).

The genotoxic and mutagenic effects observed in the present study are at least partly related to the presence of toxic organic substances, such as cresol, as well as the synergistic effects of all of the substances present in the SS. According to ATSDR (2008), positive results obtained from in vitro tests performed in humans and animals suggest that cresols can react with DNA, thereby inducing genotoxicity. These compounds are also reported to be possible human carcinogens. Although the results of our chemical analyses indicate an absence of substances exceeding the limits established by legislation, significant genotoxic and mutagenic effects were observed for the species A. cepa after 6 and 12 months of attenuation, suggesting the presence of other substances that were not chemically identified in the SS because measurement of these substances is not required by legislation regarding the use of SS in agricultural environments. Another hypothesis related to the observed effects concerns the synergism of contaminants, which may be responsible for these results. The presence of dioxins and furans does not appear to be harmful to A. cepa because the concentrations of these substances in the samples increased over the examined periods of natural attenuation, while the detected cellular effects decreased.

However, because SS is a complex matrix, it is difficult to predict which substances are responsible for this effect, which reinforces the need to perform biological assays concomitantly with chemical analyses to better understand the potential risks of SS (Oleszczuk, 2008).

Although significant cytotoxic, genotoxic and mutagenic effects were observed in the present study, all of the assessed parameters indicated a reduction of the effects induced by the SS over the evaluated period of natural attenuation, particularly for the soil/SS associations. According to Wong et al. (1983), processes resulting in the stabilization of SS may decrease the toxicity of this waste. However, although the process of natural attenuation was effective in reducing the harmful effects of the soil/SS associations, the
$100 \%$ SS did not appear suitable for agricultural applications even after 12 months of attenuation.

The results obtained in the assays performed with the raw SS and the aqueous SS extracts were very similar, which indicates that contaminants present in the SS responsible for the effects observed in A. cepa are bioavailable in the samples. An important point for consideration in the application of SS is that the presence of toxic substances in an aqueous extract indicates that these compounds can be transported by water and may thus be able to reach and contaminate deeper soil layers as well as groundwater and adjacent water resources. Although most studies report the presence of heavy metals in SS lixiviates (Mcbride et al., 1997; Keller et al., 2002; Bhogal et al., 2003), we emphasize that organic substances, such as cresol, may also be transported by water and should be considered major SS pollutants.

\section{Conclusion}

The chemical analyses revealed the presence of harmful compounds such as $m$ - and $p$-cresol at high concentrations in the initial samples of SS ( 0 and 2 months). The results obtained in the A. cepa test demonstrated that the studied SS was potentially genotoxic and mutagenic to cells, even when present at low concentrations in association with soil. Thus, the application of SS in agricultural soils should not be implemented prior to evaluate its toxic potential because it may endanger exposed organisms and constitute a potential pollutant of both terrestrial and aquatic environments.

However, based on the reduction of the effects of the SS observed in the test organism A. cepa and on the absence of the toxic compounds observed in the chemical analysis, it can be concluded that monitored natural attenuation appears to be a very efficient and cost-effective method for the removal of toxic organic substances present in SS, such as $m$ - and $p$-cresol. A period of 12 months of natural attenuation proved to be sufficient to decrease the toxicity of the soil/SS associations, proving to be a sustainable method to transform this waste in agricultural soils amendment. However, for the disposal of $100 \%$ SS (raw sludge), we recommend that the material undergo an attenuation period of more than 12 months to allow total elimination of its toxic effects.

Regarding the microbiological characterization of the SS, an alternation in microbial community was observed among enterobacteria and Gram-positive cocci during the initial periods and non-fermenter bacteria during the final period (12 months), serving as indicators of the attenuation process. The bacteria Bacillus sp., E. cloacae, P. rettgeri, M. morganii, $P$. mirabilis and a non-fermenter Gram-negative bacilli seem to be the main microorganisms involved in the degradation of toxic compounds present in the SS, such as $m$ - and p-cresol and bis(2-ethylhexyl)phthalate, but they were not capable of degrading dioxins and furans.

The species A. cepa was shown to be an efficient test organism for detecting toxic effects induced by SS contaminants. The chromosomal aberrations and micronuclei assays performed in this organism were demonstrated to be very sensitive tools for detecting cellular damage induced by this type of residue.

\section{Acknowledgements}

The authors would like to thank the Foundation for Research Support of São Paulo State-FAPESP, Process n. 2009/09665-0, for financial support; the company Odebrecht Ambiental, for providing the SS used in this study; and Prof. Dr. Dejanira Francheschi de Angelis, from the Department of Biochemistry and Microbiology, Institute of Biosciences, UNESP, Rio Claro, for providing laboratory facilities for performing some steps of this work that were 
necessary to characterize the SS samples and prepare solubilized SS.

\section{Appendix A. Supplementary data}

Supplementary data associated with this article can be found, in the online version, at http://dx.doi.org/10.1016/j.ecolind. 2015.03.026.

\section{References}

ABNT-Associação Brasileira de Normas Técnicas, 2004. NBR 10006: Procedimento para obtenção de extrato solubilizado de resíduos sólidos (Procedure for Obtention of Solubilized Extraction of Solid Wastes). ABNT, Rio de Janeiro.

Arya, D., Kumar, S., Kumar, S., 2011. Biodegradation dynamics and cell maintenance for the treatment of resorcinol and $p$-cresol by filamentous fungus Gliomastix indicus. J. Hazard. Mater. 198, 49-56.

ATSDR-Agency for Toxic Substances and Disease Registry, 2008. Toxicological Profile for Cresols. ATSDR, Atlanta.

Azarova, I.N., Parfenova, V.V., Baram, G.I., Terkina, I.A., Pavlova, O.N., Suslova, M.Y., 2003. Degradation of bis-(2-ethylhexyl)phthalate by microorganisms of the water and bottom sediments of the Selenga River and Lake Baikal under experimental conditions. Appl. Biochem. Microbiol. 39, 585-589.

Bhogal, A., Nicholson, F.A., Chambers, B.J., Shepherd, M.A., 2003. Effects of past sewage sludge additions on heavy metal availability in light textured soils: implications for crop yields and metal uptakes. Environ. Pollut. 121, 413-423.

Bright, D.A., Healey, N., 2003. Contaminant risks from biosolids land application: contemporary organic contaminant levels in digested sewage sludge from five treatment plants in Greater Vancouver, British Columbia. Environ. Pollut. 126, 39-49.

Caritá, R., 2007. Avaliação do potencial genotóxico e mutagênico de amostras de lodos provenientes de estações de tratamento de esgoto de grandes centros urbanos do Estado de São Paulo, pela metodologia de aberrações cromossômicas em Allium cepa. Monograph, UNESP-Universidade Estadual Paulista, Rio Claro.

Caritá, R., Marin-Morales, M.A., 2008. Induction of chromosome aberrations in the Allium cepa test system caused by the exposure of seeds to industrial effluents contaminated with azo dyes. Chemosphere 72, 722-725.

Carrara, S.M.C.M., Morita, D.M., Boscov, M.E.G., 2011. Biodegradation of di(2ethylhexyl)phthalate in a typical tropical soil. J. Hazard. Mater. 197, 40-48.

Christofoletti, C.A., Francisco, A., Fontanetti, C.S., 2012. Biosolid soil application: toxicity tests under laboratory conditions. Appl. Environ. Soil Sci. 2012, 01-09.

Clarke, B.O., Smith, S.R., 2011. Review of 'emerging' organic contaminants in biosolids and assessment of international research priorities for the agricultural use of biosolids. Environ. Int. 37, 226-247.

Fortnagel, P., Harms, H., Wittich, R.M., Krohn, S., Meyer, H., Sinnwell, V., Wilkes, H., Francke, W., 1990. Metabolism of dibenzofuran by Pseudomonas sp. strain HH69 and the mixed culture HH27. Appl. Environ. Microbiol. 56, 1148-1156.

Gray, N.F., 2010. Sludge treatment and disposal. In: Gray, N.F. (Ed.), Water Technology. An Introduction for Environmental Scientists and Engineers. Butterworth-Heinemann, Oxford, pp. 645-685.

Habe, H., Ide, K., Yotsumoto, M., Tsuji, H., Yoshida, T., Nojiri, H., Omori, T., 2002. Degradation characteristics of a dibenzofuran-degrader Terrabacter sp. strain DBF63 toward chlorinated dioxins in soil. Chemosphere 48, 201-207.

Harrison, E.Z., Oakes, S.R., Hysell, M., Hay, A., 2006. Organic chemicals in sewage sludges. Sci. Total Environ. 367, 481-497.

Ho, K.L., Chen, Y.Y., Lee, D.J., 2010. Functional consortia for cresol-degrading activated sludges: toxicity-to-extinction approach. Bioresour. Technol. 101, 9000-9005

Holmstrup, M., Krogh, P.H., Lokke, H., de Wolf, W., Marshall, S., Fox, K., 2001. Effects and risk assessment of linear alkylbenzene sulfonates in agricultural soil, 4 . The influence of salt speciation, soil type, and sewage sludge on toxicity using the collembolan Folsomia fimetaria and the earthworm Aporrectodea calginosa as test organisms. Environ. Toxicol. Chem. 20, 1680-1689.

IPCS. International Programme on Chemical Safety, 1995. No. 168: Cresols, EHC (Environmental Health Criteria). World Health Organization, Geneva.

Jiang, W., Fan, W., 2008. Bioremediation of heavy metal-contaminated soils by sulfate-reducing bacteria. Ann. N.Y. Acad. Sci. 1140, 446-454.

Juneson, C., Ward, O.P., Singh, A., 2001. Biodegradation of bis(2-ethylhexyl)phthalate in a soil slurry-sequencing batch reactor. Process. Biochem. 37, 305-313.

Keller, C., Mcgrath, P., Duham, S.J., 2002. Trace metal leaching through a soil-grassland system after sewage sludge application. J. Environ. Qual. 31, 1550-1560

Klimm, C., Schramm, K.W., Henkelmann, B., Martens, D., Kettrup, A., 1998. Formation of octa- and heptachlorodibenzo-p-dioxins during semi anaerobic digestion of sewage sludge. Chemosphere 37, 2003-2011.

Kulkarni, P.S., Crespo, J.G., Afonso, C.A.M., 2008. Dioxins sources and current remediation technologies: a review. Environ. Int. 34, 139-153.

Leblanc, R.J., Matthews, P., Richard, R.P., 2008. Global Atlas of Excreta, Wastewater Sludge, and Biosolids Management: Moving Forward the Sustainable and Welcome Uses of a Global Resource Welcome Uses of a Global Resource. United Nations Human Settlements Programme (UN-HABITAT), Nairobi.
Leme, D.M., Marin-Morales, M.A., 2008. Chromosome aberration and micronucleus frequencies in Allium cepa cells exposed to petroleum polluted water-a case study. Mutat. Res. 650, 80-86.

Makadia, T.H., Adetutu, E.M., Simons, K.L., Jardine, D., Sheppard, P.J., Ball, A.S., 2011 Re-use of remediated soils for the bioremediation of waste oil sludge. J. Environ. Manage. 92, 866-871.

Matamoros, V., Nguyen, L.X., Arias, C.A., Nielsen, S., Laugen, M.M., Brix, H., 2012. Musk fragrances, DEHP and heavy metals in a 20 years old sludge treatment reed bed system. Water Res. 46, 3889-3896.

Mazzeo, D.E.C., Levy, C.E., Angelis, D.F., Marin-Morales, M.A., 2010. BTEX biodegradation by bacteria from effluents of petroleum refinery. Sci. Total Environ. 47, 1255-1264.

Mazzeo, D.E.C., Fernandes, T.C.C., Marin-Morales, M.A., 2011. Cellular damages in the Allium cepa test system, caused by BTEX mixture prior and after biodegradation process. Chemosphere 85, 13-18.

Mazzeo, D.E.C., Marin-Morales, M.A., 2015. Genotoxicity evaluation of environmental pollutants using analysis of nucleolar alterations. Environ. Sci. Pollut. Res. http://dx.doi.org/10.1007/s11356-015-4134-2.

Mcbride, M.B., Richards, B.K., Steenhuis, T., Russo, J.J., Sauvé, S., 1997. Mobility and solubility of toxic metals and nutrients in soil fifteen years after sludge application. Soil Sci. 162, 487-500.

Ministério do Meio Ambiente, Conselho Nacional do Meio Ambiente, 2006 Resolução n॰ 375, de 29 de agosto de. MMA, Brasília.

Miranda, R.C.M., Gomes, E.B., Pereira Jr., N., Marin-Morales, M.A., Machado, K.M.G. Gusmão, N.B., 2013. Biotreatment of textile effluent in static bioreactor by Curvularia lunata URM 6179 and Phanerochaete chrysosporium URM 6181. Bioresour. Technol. 142, 361-367.

Mohite, B.V., Pawar, S.P., Morankar, A., 2011. Isolation, selection and biodegradation profile of phenol degrading bacteria from oil contaminated soil. Bull. Environ. Contam. Toxicol. 87, 143-146.

Moreira, R., Sousa, J.P., Canhoto, C., 2008. Biological testing of a digested sewage sludge and derived composts. Bioresour. Technol. 99, 8382-8389.

Niazi, J.H., Prasad, D.T., Karegoudar, T.B., 2001. Initial degradation of dimethylphthalate by esterases from Bacillus species. FEMS Microbiol. Lett. 196, 201-205.

OECD Organisation for Economic Co-operator and Development, 2003. SIDS Initial Assessment Report. $m$-/p-Cresol. UNEP Publications, Paris.

Oleszczuk, P., 2008. Phytotoxicity of municipal sewage sludge composts related to physic-chemical properties, PHAs and heavy metals. Ecotoxicol. Environ. Saf. 69 496-505.

Opeolu, B.O., Fatoki, O.S., Odendaal, J., 2010. Development of a solid-phase extraction method followed by HPLC-UV detection for the determination of phenols in water. Int. J. Phys. Sci. 5, 576-581.

Park, J.H., Lamb, D., Paneerselvam, P., Choppala, G., Bolan, N., Chung, J.W., 2011. Role of amendments on enhanced bioremediation of heavy metal(loid) contaminated soils. J. Hazard. Mater. 185, 549-574.

Parsons, J.R., Bruijne, J.A., Weiland, A.R., 1998. Biodegradation pathway of 2 chlorodibenzo-p-dioxin and 2-chlorodibenzofuran in the biphenyl-utilising strain JB1. Chemosphere 37, 1915-1922.

Petersen, S.O., Henriksen, K., Mortensen, G.K., Krogh, P.H., Brandt, K.K., Sørensen, J. Madsen, T., Petersen, J., Grøn, C., 2003. Recycling of sewage sludge and household compost to arable land: fate and effects of organic contaminants, and impact on soil fertility. Soil Tillage Res. 72, 139-152.

Plaza, G., Nalęcz-Jawecki, G., Ulfig, K., Brigmon, R.L., 2005. The application of bioassays as indicators of petroleum-contaminated soil remediation. Chemosphere 59, 289-296.

Pradhan, N., Ingle, A.O., 2007. Mineralization of phenol by Serratia plymuthica strain GC isolated from sludge sample. Int. Biodeterior. Biodegrad. 60, 103-108.

Roig, N., Sierra, J., Nadal, M., Martí, E., Navalón-Madrigal, P., Schumacher, M. Domingo, J.L., 2012. Relationship between pollutant content and ecotoxicity of sewage sludges from Spanish wastewater treatment plants. Sci. Total Environ. 425, 99-109.

Roos, P.H., Tschirbs, S., Pfeifer, F., Welge, P., Hackc, A., Wilhelm, M., Bolt, H.M., 2004. Risk potentials for humans of original and remediated PAH-contaminated soils: application of biomarkers of effect. Toxicology 205, 181-194.

Sánchez-Brunete, C., Miguel, E., Tadeo, J.L., 2007. Analysis of 27 polycyclic aromatic hydrocarbons by matrix solid-phase dispersion and isotope dilution gas chromatography-mass spectrometry in sewage sludge from the Spanish area of Madrid. J. Chromatogr. A 1148, 219-227.

Saravanan, P., Pakshirajan, K., Saha, P., 2008. Biodegradation of phenol and $m$-creso in batch and fed batch operated internal loop airlift bioreactor by indigenous mixed microbial culture predominantly Pseudomonas sp. Bioresour. Technol. 99 8553-8558.

Sen, B.K., Deshmukh, D.K., Deb, M.K., Verma, D., Pal, J., 2014. Removal of phenolic compounds from aqueous phase by adsorption onto polymer supported iron nanoparticles. Bull. Environ. Contam. Toxicol. 93, 549-554.

Sharma, A., Kachroo, D., Kumar, R., 2002. Time dependent influx and efflux of pheno by immobilized microbial consortium. Environ. Monit. Assess. 76, 195-211.

Singh, S., Chandra, R., Patel, D.K., Rai, V., 2007. Isolation and characterization of nove Serratia marcescens (AY927692) for pentachlorophenol degradation from pulp and paper mill waste. World J. Microboiol. Biotechnol. 23, 1747-1754.

Souza, T.S., Hencklein, F.A., Angelis, D.F., Fontanetti, C.S., 2013. Clastogenicity of landfarming soil treated with sugar cane vinasse. Environ. Monit. Assess. 185, $1627-1636$

Srivastava, R., Kumar, D., Gupta, S.K., 2005. Bioremediation of municipal sludge by vermitechnology and toxicity assessment by Allium cepa. Bioresour. Technol. 96, 1867-1871. 
Suzuki, Y., Nakamura, M., Otsuka, Y. Suzuki, N., Ohyma, K., Kawakami, T., Sato, K., Kajita, S., Hishiyama, S., Fujii, T., Takahashi, A., Katayama, Y., 2011. Novel enzymatic activity of cell extract from thermophilic Geobacillus sp, UZO 3 catalyses reductive cleavage of diaryl ether bonds of 2,7-dichorodibenzo-p-dioxin. Chemosphere 83, 868-872.

Tallur, P.N., Megadi, V.B., Kamanavalli, C.M., Ninnekar, H.Z., 2006. Biodegradation of p-cresol by Bacillus sp. strain PHN 1. Curr. Microbiol. 53, 529-533.

Tallur, P.N., Megadi, V.B., Ninnekar, H.Z., 2009. Biodegradation of $p$-cresol by immobilized cells of Bacillus sp. strain PHN 1. Biodegradation 20, 79-83.

Tas, D.O., 2010. Respirometric assessment of aerobic sludge stabilization. Bioresour. Technol. 101, 2592-2599.

Tsakou, A., Roulia, M., Christodoulakis, N.S., 2001. Growth of cotton plants (Gossyp ium hirsutum) as affected by water and sludge from a sewage treatment plant: II. Seed and fiber yield and heavy metal accumulation. Bull. Environ. Contam. Toxicol. 66, 743-747.

USEPA-United States Environmental Protection Agency), 1999a. Use of Monitored Natural Attenuation at Superfund, RCRA Corrective Action, and Underground Storage Tank Sites. Office of Solid Waste and Emergency Response, Washington, DC.
USEPA-United States Environmental Protection Agency, 1999b. SW-846. Test Methods for Evaluating Solid Waste, Physical Chemical Methods. USEPA-United States Environmental Protection Agency, Washington, DC.

Walter, I., Martínez, F., Cala, V., 2006. Heavy metal speciation and phytotoxic effects of three representative sewage sludges for agricultural uses. Environ. Pollut. 139, 507-514.

Weber, R., Yoshida, S., Miwa, K., 2002. PCB destruction in subcritical and supercritical water evaluation of PCDF formation and initial steps of degradation mechanisms. Environ. Sci. Technol. 36, 1839-1844.

Wilkes, H., Wittich, R.M., Timmis, K.N., Fortnagel, P., Francke, W., 1996. Degradation of chlorinated dibenzofurans and dibenzo-p-dioxins by Sphingomonas sp. strain RW1. Appl. Environ. Microbiol. 62, 367-371.

Wong, M.H., Cheung, Y.H., Cheung, C.L., 1983. The effects of ammonia and ethylene oxide in animal manure and sewage sludge on the seed germination and root elongation of Brassica parachinensis. Environ. Pollut. 30, 109-123.

Yuan, S.Y., Huang, I.C., Chang, B.V., 2010. Biodegradation of dibutyl and di-(2ethylhexyl)phthalate and microbial community changes in mangrove sediment. J. Hazard. Mater. 184, 826-831. 